\title{
CONCERNING ALL DAY CONVERSATIONS
}

\section{By MARGARET MORSE NICE}

It requires courage to attempt to record everything a child will say in one day, and it certainly takes determination, persistence and hard work to carry it through. I do not wonder that there are <so few published instances. M. C. and H. Gale ('00) were the pioneers in this line; they recorded no less than eleven all day conversations of children from twenty to thirty months old. In all of these they worked out the number of different words and ten of them they analyzed with great care. Bell ('03) has the distinction of reporting the largest number of words spoken by children in one day, but unfortunately he gives no other data. I (1917) tried to take the all day conversations of my three and five year old daughters, but did not succeed in recording everything, so my results were confined to the number of sentences said, the average number of words in a sentence and the approximate total number of words. G. C. and Julia Brandenburg ('15 and '19) have done the most thorough and admirable work not only in taking conversations but in working them up. They had the unexampled zeal to take two whole day conversations of their child when three and one when four, analyzing the data in two of these in great detail.

Fired by the Brandenburgs' achievement, we thought we ought to be able to get a complete day's account of our four year old, especially as we were sure she was much less talkative than their child. The birthday of our third daughter, R, came August 9th; I wished to take her all day conversation about a month before as a basis for collecting her four year vocabulary. On July 1st I tested myself by writing down every word she said for half an hour, and when I had achieved that, I saw that an all day's record was possible. We chose July 3rd, as on that day both her father and myself could devote ourselves to the task in hand, her father spelling me in the writing when I had some other unavoidable occupation. The little girl was entirely unconscious of the attention she was receiving.

$\mathrm{R}$ had been late in learning to talk (Nice, '18). She had an exceedingly small vocabulary at three and it was not until she was forty months old that she seemed really to make up her mind to talk. She learned with great rapidity from then on, so that by the age of four she had a fair sized 
vocabulary-1,135 words; this is smaller than any that have been published for this age except Mateer's brother ('08) who had 1,020 words; he also was late in beginning to talk. R's sentences were short at this time and many small words were omitted.

Hourly Record.

The number of words and sentences used each hour are shown in the following table.

TABLE 1 HOURLY RECORD OF

THE ALL DAY CONVERSATION

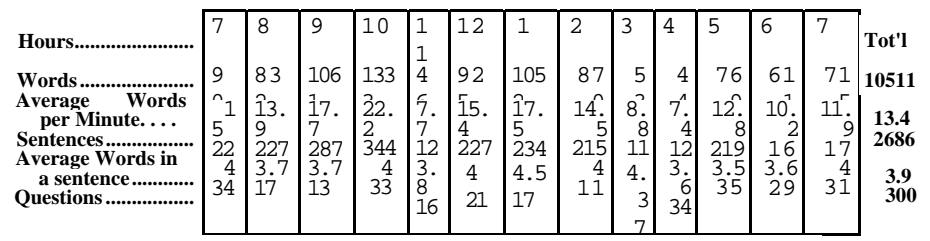

$\mathrm{R}$ talked more in the morning than in the afternoon, for in the six morning hours she used 5,519 words and only 4,992 in the seven afternoon hours. The hour that she talked the most was from 10 to 11 when she used 1,333 words while playing with a three year old boy; the other most talkative hours were from 9 to $10-1,061$ words - when playing outside with several children; from 1 to 2-1,052 wordswhen telling a story and working with Montessori colors; 12 to $1-925$ words - the dinner hour; and 7 to 8 A. M.—902 words - when she first got up in the morning. The least talkative hour was from 4 to 5-444 words-when she was on a walk. The other two hours in which she spoke comparatively little were from 11 to $12-464$ words-and 3 to 4 -531 words; - during a part of each of these periods her father was reading to her.

By dividing the number of words each hour by 60 we find the average number of words spoken per minute. Of course she did not talk three times as fast one hour as another; it is rather the relative amount of silence that is indicated. The average for the whole day is 13.4 words a minute; the different hours vary from 7.4 to 22.2.

She used 2,686 sentences, the average number of words in a sentence being 3.9. The shortness of her sentences indicates her retardation, placing her status in skill of speech below the average three year old child. 193 of these sentences-7.2 per cent-were repeated; 20 per cent of Brandenburg's daughter's sentences at three were repetitions. 
She asked 300 questions, an average of 23 an hour. Questions comprise 11.2 per cent of her sentences; those of Brandenburg's child were 23 per cent at three, and 20 per cent at four. More than half of these occurred in the afternoon; this differs with Brandenburg's results with the three year conversation but agrees with the four year.

Comparison with Other Children.

In the following table I have summarized the published all day conversations of children two and a half and over; I have also included that of one two year old boy as its large size makes it valuable for comparison with the others.

TABLE II COMPARISON OF TEN

ALl Day Conversations

\begin{tabular}{|c|c|c|c|c|c|c|c|c|c|}
\hline Author & Child & Age & $\begin{array}{l}\text { Total } \\
\text { Words }\end{array}$ & $\begin{array}{l}\text { Words } \\
\text { Per } \\
\text { Minute }\end{array}$ & $\begin{array}{l}\text { Differ- } \\
\text { ent } \\
\text { Words }\end{array}$ & $\begin{array}{l}\text { Per Cent } \\
\text { of Vocab- } \\
\text { ulary }\end{array}$ & $\begin{array}{l}\text { Aver. } \\
\text { Use of } \\
\text { Each } \\
\text { Word }\end{array}$ & $\begin{array}{l}\text { No. } \\
\text { of } \\
\text { Sent- } \\
\text { ences }\end{array}$ & \begin{tabular}{|l} 
Aver. \\
Words \\
in \\
Sent- \\
ence
\end{tabular} \\
\hline Gale & \multirow{7}{*}{$\begin{array}{l}\text { Boy, C } \\
\text { Boy, S } \\
\text { Girl } \\
\text { Girl, D } \\
\text { Girl, G } \\
\text { Girl, A } \\
\text { Girl, R } \\
\text { Girl, G } \\
\text { Girl, B } \\
\text { Girl, E }\end{array}$} & \multirow{7}{*}{$\begin{array}{l}21 / 2 \\
21 / 2 \\
2 \\
3 \\
31 / 2 \\
31 / 2 \\
4 \\
4 \\
4 / 2 \\
5\end{array}$} & \multirow{7}{*}{\begin{tabular}{|l|}
10507 \\
9290 \\
8992 \\
7600 \\
11628 \\
15230 \\
10511 \\
14930 \\
14992 \\
10500
\end{tabular}} & \multirow{7}{*}{$\begin{array}{ll}15.2 \\
13.4 \\
13 \\
10.6 \\
16 \\
21 \\
13.4 \\
20 \\
20 \\
13.4\end{array}$} & \multirow{3}{*}{$\begin{array}{l}805 \\
751 \\
629\end{array}$} & \multirow{3}{*}{$\begin{array}{l}52.5 \\
41.6\end{array}$} & \multirow{3}{*}{$\begin{array}{r}13 \\
12.4 \\
14.3\end{array}$} & & \\
\hline Gale. & & & & & & & & & \\
\hline Cale & & & & & & & & \multirow{2}{*}{\begin{tabular}{|l|}
2018 \\
1873
\end{tabular}} & 3.77 \\
\hline \multirow{2}{*}{$\begin{array}{l}\text { Brandenburg.. } \\
\text { Bell. }\end{array}$} & & & & & 859 & 34 & 13.7 & & \begin{tabular}{|l|}
6.6 \\
\end{tabular} \\
\hline & & & & & 731 & 54.524 & 14.4 & 2686 & 3.9 \\
\hline \multirow{2}{*}{$\begin{array}{l}\text { Brandenburg.. } \\
\text { Bell. }\end{array}$} & & & & & 999 & & 14.9 & 1967 & 7.5 \\
\hline & & & & & & & & 1702 & 6.17 \\
\hline
\end{tabular}

Just as most of the vocabulary studies have been made on girls, so in these all day conversations boys are sadly in the minority. Parents of boys must come to the rescue and give us data on their sons.

In total words, Bell's two girls lead, the three and a half year child having the most-15,230. His four and a half year daughter and Brandenburg's daughter at four have nearly as many-14,992 and 14,930 respectively. Brandenburg's daughter at three us :d 3,000 fewer words than a year later, saying 11,620 . Close to this are three records in the 10,000 group, my children- $\mathrm{R}$ at four years and $\mathrm{E}$ at five- and Carl Andrist at two. Then came Gale's son at two and a half with 9,290 words, his daughter at the same age with 8,992 and my daughter D at three with 7,600 .

The number of words per minute varies from 10.6 to 20 . In the case of different children there are doubtless two factors involved in these variations; first, some children speak faster than others and second, some chatter almost incessantly, while others are silent a part of the time.

The number of different words is known in six cases; it 
varies from 629 of Gale's daughter to 999 of Brandenburg's daughter at four.

The percentage of the total vocabulary used in any one day is an index to the child's maturity; the younger the child, the larger, as a rule, will the percentage be. Gale has published the most complete series of all day conversations of any child. His daughter used 96.3 per cent of her total vocabulary at 20 months, 60.7 per cent at 21 months and 43.1 per cent at 22 months. The next two times are an exception to the rule for she used 48.6 per cent of her vocabulary at 23 months and 53.4 per cent at 26 months. However at 30 months the proportion is the lowest of all-41.6 per cent. Brandenburg's daughter shows the typical development, for she used 34 per cent of her vocabulary at three and 24 per cent at four. R's high percentage-54.5-is another indication of her lack of development in speech matters. This is almost the same as Gale's boy of two and a half; indeed R's figures are more similar to his than to those of any of the other children; their total words, different words and percentage of whole vocabularies are nearly the same, while the rate of words per minute is just the same.

The average number of times each word was used shows more uniformity than any other item; it varies from 12.4 to 14.9 in the six cases in which it can be calculated.

As to the length of sentences, the five children for whom we know it, divide themselves into two groups. $\mathrm{D}$ at three and $\mathrm{R}$ at four used short sentences - 3.77 and 3.9 words respectively; while Brandenburg's child at three and four and $E$ at five used sentences of 6.6, 7.5 and 6.17 words respectively. D ('18) was slow in beginning to talk and had not advanced at this time as far as the average three year old.

The Parts of Speech.

The distribution of the different words of her all day conversation is shown in Table III and also the percentages of the parts of speech in her whole vocabulary.

Forty-eight of these nouns were proper nouns and 10 were nonsense or words repeated after some one else; 33 of the verbs and 3 of the adjectives were inflections, while 7 of the interjections were nonsense, so that only 619 of these words were counted in making up her four year vocabulary.

The parts of speech of the different words follow in general the proportions of the parts of speech in the whole vocabulary of the child. Nouns were less used, while verbs, adverbs, pronouns and prepositions have higher percentages in the one day vocabulary than in the whole vocabulary. These percentages are much the same as those of Brandenburg's 
TABLE III PARTS OF SPEECH

OF THE DIFFERENT WORDS

\begin{tabular}{lrrc} 
& Number & Per Cent & $\begin{array}{l}\text { Per Cent in Whole } \\
\text { Vocabulary }\end{array}$ \\
Nouns & & & 52.2 \\
Verbs & 302 & 41.4 & 23.2 \\
Adiectives & 192 & 27.6 & 11.2 \\
Adverbs & 90 & 12.4 & 7.6 \\
Pronouns & 69 & 9.5 & 2.9 \\
Prepositions & 32 & 4.3 & 1.6 \\
Interiections & 18 & 2.5 & 0.4 \\
Conjunctions & 14 & 1.9 & 0.9 \\
\cline { 3 - 4 } & 3 & 0.4 & 100.0
\end{tabular}

child at four. Gale's son and daughter at two and a half used similar percentages as R, except that their nouns were higher, being 47.8 and 48 per cent; and their adverbs were lower- 5.5 and 6 per cent.

The proportion of the parts of speech of the total words of her day's speech are decidedly different as shown in Table IV.

TABLE IV

PARTS OF SPEECH OF THE TOTAL WOR

$\begin{array}{lcr} & \text { Number } & \text { Per Cent } \\ \text { Verbs } & 2966 & 28.2 \\ \text { Pronouns } & 2328 & 22.1 \\ \text { Nouns } & 2040 & 19.5 \\ \text { Adverbs } & 1676 & 16.0 \\ \text { Adjectives } & 772 & 8.6 \\ \text { Prepositions } & 585 & 5.6 \\ \text { Interiections } & 97 & 0.9 \\ \text { Conjunctions } & 47 & 0.4\end{array}$

10511

100.0

It will be seen that she used more verbs than any other parts of speech, more than a fourth of all her words denoting action. Over a fifth were pronouns and less than a fifth nouns. The next largest division was adverbs, comprising about a sixth of her total conversation and after them adjectives which she used only half as often. It is interesting and rather unexpected to find that half of the 10,000 words this child used in one day were verbs and pronouns. We should have data on older children and adults for purposes of comparison.

Each word was used on an average 14.4 times. There is 
great variation, however in the number of times the words of each part of speech occurred as shown in Table V.

\section{TABLE V AVERAGE NUMBER OF}

\section{TIMES EACH WORD WAS USED}

$\begin{array}{lllr}\text { Pronouns } & 72.7 & \text { Verbs } & 15.5 \\ \text { Prepositions } & 32.5 & \text { Adjectives } & 9.0 \\ \text { Adverbs } & 24.5 & \text { Interiections } & 7.0 \\ \text { Conjunctions } & 16.0 & \text { Nouns } & 6.8\end{array}$

In this category pronouns lead, since each was used on an average the surprising number of 72.7 times. Prepositions and adverbs were also used very frequently, 32.5 and 24.5 times respectively. Conjunctions and verbs come in a middle class being employed about the same number of times as the average for the whole vocabulary. Adjectives, interjections and nouns were used the least often, the average use of each noun being less than a tenth of the average use of each pronoun. Of course this means that with pronouns, prepositions and adverbs, relatively few words were used many, many times, while with adjectives and nouns a wide variety of words were used a few times each.

Much the same thing is evident in the proportions that her one day vocabulary bears to her whole vocabulary as shown in Table VI.

TABLE VI

PROPORTION OF ONE DAy WORDS TO WhOle VocabUlary

\begin{tabular}{|c|c|c|c|}
\hline $\begin{array}{l}\text { Parts of } \\
\text { Speech }\end{array}$ & $\begin{array}{l}\text { Per Cent Used } \\
\text { in One Day }\end{array}$ & $\begin{array}{l}\text { Parts of } \\
\text { Speech }\end{array}$ & $\begin{array}{l}\text { Per Cent Used } \\
\text { in One Day }\end{array}$ \\
\hline $\begin{array}{l}\text { repositions } \\
\text { ronouns } \\
\text { dverbs } \\
\text { onjunctions }\end{array}$ & $\begin{array}{r}100.0 \\
96.9 \\
79.3 \\
75.0\end{array}$ & $\begin{array}{l}\text { Interjections } \\
\text { Adjectives } \\
\text { Verbs } \\
\text { Nouns }\end{array}$ & $\begin{array}{l}70.0 \\
69.5 \\
60.3 \\
41.2\end{array}$ \\
\hline
\end{tabular}

She used her whole stock of prepositions during this one day, 97 per cent of her pronouns, four-fifths of her adverbs, three-fourths of her adjectives, three-fifths of her verbs and two-fifths of her nouns. Again we are impressed with the lack of variety in the prepositions, pronouns, adverbs and conjunctions used by this child and at the same time the wide range of variety in her nouns.

The Most Used Words.

The accompanying list gives the words that $\mathrm{R}$ used more than 100 times during the day. 
TABLE VII THE WORDS

\author{
USED OVER 100 TIMES
}

$\begin{array}{llllll}\text { I } & 979 & \text { Babv } & 170 & \text { Do } & 121 \\ \text { Don't } & 247 & \text { No } & 161 & \text { Not } & 119 \\ \text { To } & 230 & \text { Get } & 154 & \text { This (adiective) } & 117 \\ \text { Mamma } & 215 & \text { Vec } & 150 & \text { Me } & 116 \\ \text { Want } & 210 & \text { See } & 139 & \text { Going } & 112 \\ \text { This (nronoun) } & 186 & \text { Here } & 126 & \text { On } & 103 \\ \text { Youl } & 175 & \text { It } & 134 & & \\ \text { Did } & 175 & \text { My } & 123 & & \end{array}$

This list includes 6 pronouns, 7 verbs, 4 adverbs, 2 prepositions, 2 nouns and one adjective. No conjunction nor interjection were used more than 20 times. In a similar list of an average four year old child probably, " the," " a," " is " and " am " would be represented.

The child's egocentricity is well exhibited in her use of " I " nearly one thousand times-once in every 10 words, while more than onethird of her sentences (36 per cent) had " I " for their subject. She used the various forms of the first personal pronoun 1,243 times, making their ratio to other words one to every 8.5. The second personal pronoun gives us a different picture; there are only 210 uses, which means one in every 50 words. In the case of Brandenburg's daughter the ratio of first personal pronouns at 40 months was one to every 13.5 words and at 52 months one to every 15.6. The second personal pronoun was used once for every 31.6 words at 40 months and once for every 29.8 words at 50 months. Here again we very much need further data especially on older subjects.

\title{
The One Hour Conversation.
}

The results with the all day conversations of my other children were not complete enough to enable me to analyze them as I have done with $\mathrm{R}$. Yet it seemed worth while to compare an hour's conversation of the three children. Choosing as a standard R's first hour in which she said 902 words, I took enough sentences from D's and E's all day conversations to get this same number of words; with R and $\mathrm{E}$ the time was one hour, while with D it was somewhat more as she said fewer words in an hour than her sisters. The conversation of each child embraced similar activities, dressing, breakfast and play.

In comparing the percentages of the parts of speech of R's one hour and all day conversations, we find a striking agreement in the proportions of the total words, the difference varying from 0.1 of one per cent to 2 per cent. There is 
much less agreement in the proportions of the parts of speech in the different words; indeed there is a similar relation between the one hour and one day vocabulary, as there is between the one day and one month vocabulary. That is, the proportion of nouns is too low, while that of verbs, adverbs, pronouns and prepositions is too high. Thus it seems that with the total words, one hour gives a good prophecy of the all day conversation, while with the proportions of the different words its value is much less definite.

\section{TABLE VIII}

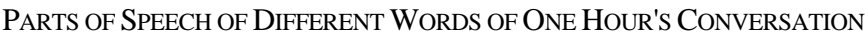

\begin{tabular}{lrrrrrr} 
& \multicolumn{3}{c}{ Numbers } & \multicolumn{3}{c}{ Per Cent } \\
& \multicolumn{1}{c}{$\mathrm{E}$} & $\mathrm{R}$ & $\mathrm{D}$ & $\mathrm{E}$ & $\mathrm{R}$ & $\mathrm{D}$ \\
Verbs & 107 & 59 & 66 & 34.1 & 30.7 & 34.0 \\
Nouns & 77 & 59 & 55 & 24.1 & 30.7 & 27.8 \\
Adverbs & 34 & 26 & 25 & 10.6 & 13.4 & 12.7 \\
Adiectives & 52 & 23 & 23 & 16.2 & 11.8 & 11.8 \\
Pronouns & 25 & 17 & 17 & 7.8 & 8.8 & 8.8 \\
Prepositions & 13 & 6 & 7 & 4.1 & 3.1 & 3.4 \\
Coniunctions & 7 & 1 & 1 & 2.2 & 0.5 & 0.5 \\
Interjections & 3 & 2 & 2 & 0.9 & 1.0 & 1.0 \\
\cline { 2 - 7 } & 318 & 193 & \multicolumn{1}{c}{$1 \%$} & 100.0 & 100.0 & 100.0 \\
& \multicolumn{5}{c}{ TABLE IX }
\end{tabular}

Parts of SPEech of Total Words of One Hour's CONVERSATION

\begin{tabular}{|c|c|c|c|c|c|c|}
\hline & \multicolumn{4}{|c|}{ Numbers } & \multicolumn{2}{|c|}{ Per Cent } \\
\hline & $\mathrm{E}$ & $\mathrm{R}$ & $\mathrm{D}$ & $\mathrm{E}$ & $\mathrm{R}$ & $\mathrm{D}$ \\
\hline Verbs & 251 & 266 & 208 & 28.1 & 29.6 & 23.1 \\
\hline Pronouns & 206 & 208 & 201 & 22.8 & 23.1 & 22.3 \\
\hline Nouns & 143 & 176 & 156 & 15.8 & 19.4 & 17.3 \\
\hline Adverbs & 93 & 126 & 167 & 10.2 & 14.0 & 18.6 \\
\hline Adjectives & 124 & 68 & 84 & 13.7 & 7.6 & 9.3 \\
\hline Prepositions & 57 & 41 & 64 & 6.2 & 4.5 & 7.1 \\
\hline Coniunctions & 19 & 3 & 6 & 2.0 & 0.3 & 0.7 \\
\hline Interjections & 12 & 14 & 14 & 1.2 & 1.6 & 1.6 \\
\hline & 905 & 902 & 900 & 100.0 & 100.0 & 100.0 \\
\hline
\end{tabular}

In examining these tables it must be remembered that $\mathrm{E}$ was five and had a vocabulary of 2,502 words, that $R$ was four with a vocabulary of 1,135 words and $\mathrm{D}$ was three with a vocabulary of 856 words. D and $\mathrm{R}$ are most astonishingly alike both in the number of the different words and in the proportion of the parts of speech With the same number 
of total words their different words are 193 and 196. E being an older child and much more advanced in the technique of talking had a far greater choice of words-318,- - which is 165 per cent of R's number. E used each word on an average 2.8 times while her sisters used each 4.7 times. D and R are also very similar in the proportions of the parts of speech; indeed, in half of them they are absolutely alike-pronouns, adjectives, conjunctions and interjections-while adverbs and prepositions differ only by one.

E's greater maturity is perhaps shown most strikingly in the matter of conjunctions - always a late acquisition; she has seven while her sisters have only one each. She has twice as many adjectives and prepositions as they. Adjectives are a specialty with E; she has a larger proportion of them in her vocabularies than most children. Proportionately E has fewer nouns and adverbs than her sisters, almost as many pronouns, about the same verbs, more prepositions and conjunctions and many more adjectives.

When we come to the table of the total words, we find less similarity than with the different words. Yet all agree in giving verbs first place and pronouns second. With E and R nouns are third in order, but with $\mathrm{D}$ they are fourth, being outstripped by adverbs which happen to be D's specialty. Adverbs come fourth with $\mathrm{R}$ but fifth with $\mathrm{E}$ where their place is usurped by adjectives. With $\mathrm{R}$ and $\mathrm{D}$ adjectives are fifth in order, being used only half as often as adverbs. All children are alike in giving sixth place to prepositions. Pronouns are the most uniform with the three, varying from 22.1 to 23.1; while adverbs show the greatest divergence, from $\mathrm{E}$ with 10.2 to R with 14 and finally $\mathrm{D}$ with 18.6.

In comparing the sixteen words used most often in R's whole day conversation and in one hour we find that fourteen are the same. The two of the hour's talk that do not correspond " going " and " me " are however among the twenty-one most used words of the all day's conversation. Therefore in her case one hour gave a fairly good index of the whole day. The words most often used by the three children during one hour are shown in the following table, and also the average number of uses of the eight words that were common to all.

Eight of these words were used by all three children: I, Mamma, to, it, my, want, you and don't. Two words in each list were used by one other child and six were individual. The words used by two children and the average number of times used are: "a," 20; "here," 16.5; and "me," 13.5. Several of E's words show her advanced status in comparison to her sisters; " the," her second commonest word, " is," her 
TABLE X

THE WORDS MOST OFTEN USED IN ONE HOUR

\begin{tabular}{|c|c|c|c|c|c|c|c|}
\hline \multicolumn{2}{|c|}{ By E } & \multicolumn{2}{|c|}{ By R } & \multicolumn{2}{|l|}{ By D } & \multicolumn{2}{|c|}{$\begin{array}{l}\text { Those Used } \\
\text { Common }\end{array}$} \\
\hline I & 56 & I & 90 & I & 69 & I & 72 \\
\hline The & 30 & Mamm & 35 & $\mathrm{Mv}$ & 36 & Mamma & 24 \\
\hline To & 23 & This (pl & & Want & 31 & To & 23 \\
\hline It & 23 & Baby & 19 & It & 31 & It & 22 \\
\hline Mother & r 21 & To & 17 & Father & 31 & $\mathrm{Mv}$ & 19 \\
\hline You & 20 & Don't & 16 & Yes & 30 & Want & 18 \\
\hline Is & 19 & You & 16 & To & 29 & You & 17 \\
\hline $\mathrm{Me}$ & 15 & Here & 16 & A & 29 & Don't & 13 \\
\hline What & 14 & Want & 13 & Up & 22 & & \\
\hline My & 11 & Going & 13 & There & 18 & & \\
\hline Don't & 11 & Me & 12 & That (pronoun) & 18 & & \\
\hline She & 11 & See & 12 & Here & 17 & & \\
\hline Am & 11 & Did & 12 & Mother & 16 & & \\
\hline A & 11 & It & 11 & You & 15 & & \\
\hline And & 11 & $\mathrm{Mv}$ & 9 & No & 14 & & \\
\hline Want & 10 & Get & 9 & Don't & 13 & & \\
\hline
\end{tabular}

seventh word, " am " and "a..' Neither of the younger children used " the ' at all and R seldom used " a." They usually omitted " am " and " is." E used " what " as a relative pronoun instead of " who," " which " and " that;" D did the same only less often for her sentences were less complicated, while $\mathrm{R}$ rarely used any relative.

The parts of speech of the eight words most commonly used by all were 1 noun, 2 verbs, 4 pronouns and 1 preposition. E's words were divided thus: 1 noun, 4 verbs, 7 pronouns, 2 adjectives, 1 preposition and 1 conjunction. $\mathrm{R}$ had 2 nouns, 6 verbs, 6 pronouns, 1 adverb and 1 preposition; while D had 2 nouns, 2 verbs, 5 pronouns, 1 adjective, 5 adverbs and 1 preposition. Perhaps the most striking difference in these lists is E's entire lack of adverbs, whereas $\mathrm{D}$ had five. $\mathrm{R}$ had no adjectives and $\mathrm{D}$ only two verbs.

E used " I " 56 times or once in every 16.2 words, while R used it 90 times, once in every 10 words. D used it 69 times, but omitted it 18 times when it should have been used, as: "Ha' (have) my ap'on on." The addition of these makes 87 uses or once in every 10.5 words. D used " you " once in every 60 words, R once in 56 and $E$ once in 45, which is just the development we would expect.

Such an array of facts and figures needs a little enliven-ment, so I will conclude with a few samples of what the children really said.

D. Three years old. Playing with toys.

Donkey goin' in autobile. Dat two toad. Goin' get dinner. Goin' come in hout (house). Big toad come to dupper (sup- 
per). 'Ner big toad a'k him to dupper. He did go adeep (asleep). Yet (yes). Goin' in autobile. I don't like 'ou to do dat. Dou naughty ding. Dat where bire (fire) id (is). Cookin' and cookin' again. I'm g'ad at him. Look at I did. Dee (see) dere. Dat b'oken. Dee dere. Cow gettin' out. No. An' hen goin' come out. Goin' on a walk. He goin' on a autobile bip (trip). Oh no. Look at dat. Dat a little bed. Bow-wow goin' to deep.

R. Four years old. In bed and being urged to go to sleep. (Sweet Cherry was an imaginary friend of wonderful prowess.)

Feet Cherry do 'tay up very late. Feet Cherry more bigger anybody in her land. She got pig name Pink and Blue. Yat baby pig she did get out. She did get out pen. She won't run away. She nice baby pig. I don't like any nap. Feet Cherry don't take any nap any more. Do you know fut (what) Feet Cherry do? Feet Cherry and me not 'faid lion. Feet Cherry got some lion. I not want any lion come here.

Feet Cherry do s'eep outdoors. In rain she do. She do in shnow. You know fut Feet Cherry do?

P'e get down yose dishes. Can't you get down yose dishes? I want yem today. After yis day tomorrow? You do say it today ev'y time. When tomorrow come?

I can't go right to s'eep. Baby do wake me up ev'y time. Can I wake up ev'ybody? Fy (why) do rabbit wake up ev'y rabbit ? I want wake up somebody. I do. I don't. I hungry. I hungry. Yes.

You know fere my sword is ? Can I get my sword ? Don't. No.

E. Five years old. Visiting in her mother's bed in the morning,

Why, I tried to get him. We went under a bridge and over a brook and under a bank and when we came back I tried to catch the frog and a great big beetle with claws. I didn't like the beetle. No, I only caught the toad. He hopped back and forth from one hand to the other. He was a young toad,

I don't like to pick up grasshoppers. They're too wibbely-wobbely. They aren't pleasant to pick up.

I don't care for paper dolls. I like animals better.

" Your noble children," why did Tabaqui say that ? When they were just born, they weren't brave, were they? I don't think any wolf was that way.

(To her baby sister.) Oh, you're making all little cunning faces. What is it, little sweetheart? She's bearing her weight 
against me. Little mischief feet! I call them little mischief feet.

You little funny-fun! You little kiss-heart!

Oh, you little bright eyes! Why do you stop and laugh at me? Mother, was she laughing at me? I like to have a baby laugh at me.

BIBLIOGRAPHY

BELL, S. 1903. The Significance of Activity in Child Life. Independent, IV, 911. BRANDENBURG, G. C. 1915. The Language of a

Three-Year-Old Child.

Ped. Sem., XXII, 89-120. ---, and J. 1919. Language Development During the Fourth Year. The Conversation. Ped Semi., XXVI, 27-40. GALE, M. C.

and H. 1900. The Vocabularies of Three Children of

One Family to Two and a Half Years of Age. Psych. Studies, No. 1, 70-117. MATEER, F. 1908. The Vocabulary of a Four Year Old Boy. Ped.

Sem., XV, 63-74. NICE, M. M. 1917. The Speech Development of a Child from Eighteen

Months to Six Years. Ped. Sem., XXIV, 204-243.

--- --- 1918. Ambidexterity and Delayed Speech Development. Ped. Sem., XXV, 141-162. 